\title{
A magia do futebol
}

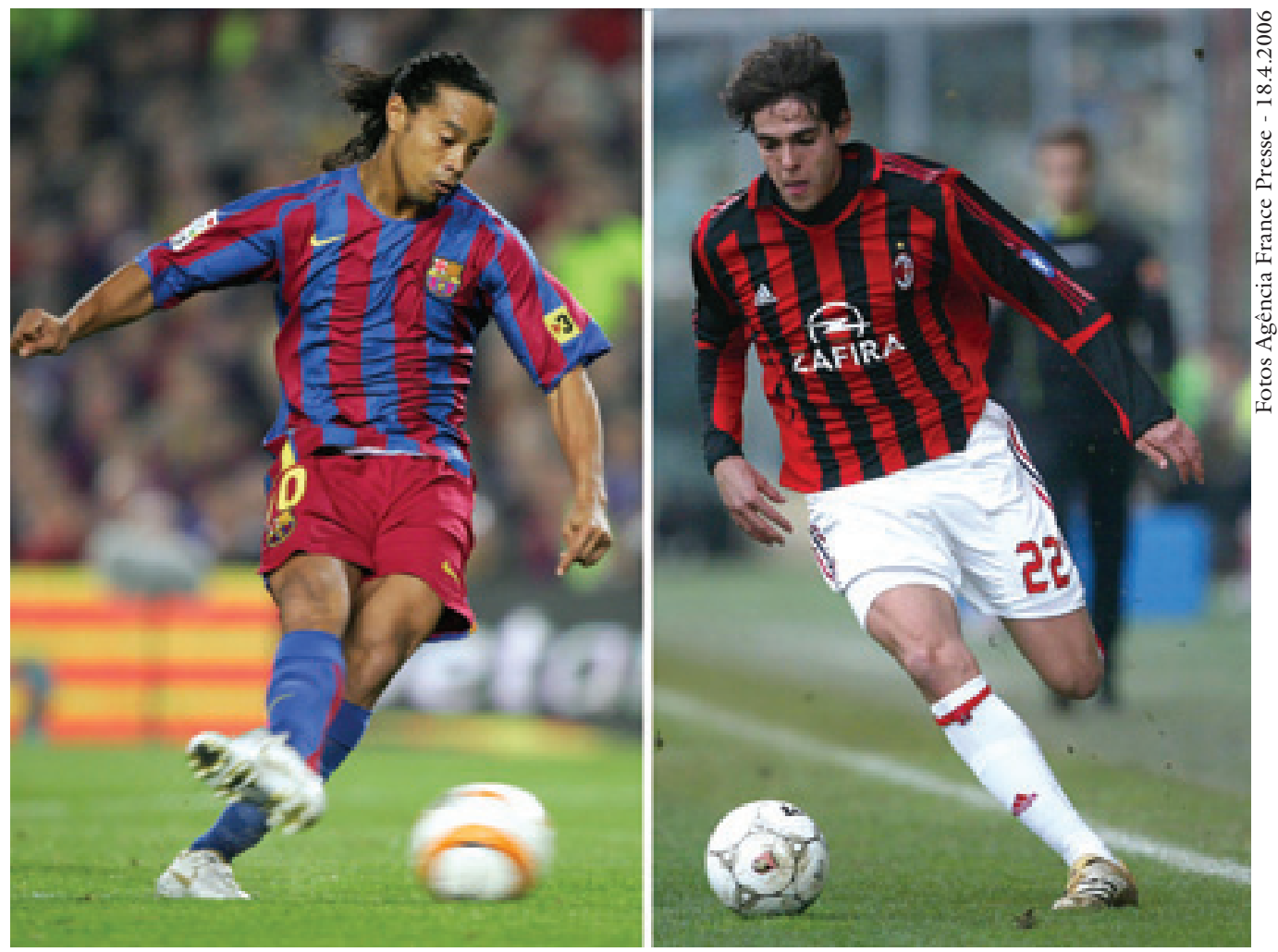

Os jogadores brasileios Ronaldinho, do Barcelona (Espanha), e Kaká, do Milan (Itália).

\section{Negócios, transações e personagens}

\section{Por Hélio Alcântara}

CCV OU SER JOGADOR de futebol profissional." Essa é uma das frases mais ouvidas entre garotos brasileiros na faixa etária compreendida entre os $12 \mathrm{e}$ os 16 anos. O curioso é que o "quero ser" foi substituído pelo "vou ser". O que, à primeira vista, pode parecer uma demonstração de absoluta autoconfiança, provavelmente é a ignorância quase total em relação aos percalços e às enormes dificuldades que essa "vontade" ou decisão representa.

A transformação do esporte mais popular do planeta Terra em "vitrine constante" e, é verdade, em algo globalizante (no sentido de amplitude e de acesso rápido) vem fazendo que os garotos e/ou pré-adolescentes “entendam” o futebol como uma atividade naturalmente fácil de ser exercida, e ainda mais fácil de ser alcançada.

A internet e a televisão têm grande parcela de responsabilidade nisso. Com 
o manejo simples do mouse ou do controle remoto, a criança e/ou o adolescente pode ter a informação que desejar a respeito dos jogadores e dos clubes preferidos, além de assistir aos campeonatos espanhol, alemão, inglês e italiano. A brutal exposição dos jogadores bem-sucedidos na mídia, sempre ligados à fama, à "aquisição" das mulheres mais bonitas e fortunas de dinheiro tem tornado esse sonho infanto-juvenil algo assustadoramente distante da realidade brasileira, mas, paradoxalmente, "parte" dessa mesma realidade. De repente, baseado em alicerce nenhum - a não ser o da idealização de um projeto -, o garoto faz uma projeção desconectada da própria realidade. É como se as crianças-adolescentes entendessem que os Ronaldos, "Kakás" e "Robinhos" representassem o verdadeiro cenário do futebol profissional. No áspero cotidiano do jogador profissional, a dor e a pobreza estão associadas quase umbilicalmente à prática desse esporte. A pirâmide salarial do futebol brasileiro mostra que $76 \%$ de todos os jogadores profissionais atuando no país ganham até dois salários mínimos (cerca de R $\$ 700,00$ ) mensais, $21 \%$ faturam entre dois e 20 salários mínimos, e apenas 3\% ganham acima de 20 salários mínimos (Rogério Ceni e Ricardinho, os únicos que atuam no Brasil convocados para a Copa, na Alemanha, ganham cerca de R\$ 300 mil cada um).

Esses dados não são revelados pela mídia com a mesma freqüência e fervor. O espetáculo futebol tem de ser vendido, e rapidamente. As cifras em torno de contratações e vendas de jogadores pipocam nos jornais, nas revistas e na televisão com tamanha naturalidade que chegamos a pensar: "Meu salário é um acinte!". Basta darmos uma olhada nos valores relacionados ao faturamento de alguns dos jogadores mais famosos do planeta Terra.

Os 10 jogadores que mais ganharam dinheiro em 2005 (em euros):

1) Ronaldinho "Gaúcho" (Barcelona): E\$ 23 milhões*

2) David Beckham (Real Madrid): E\$ 18 milhões

3) Ronaldo "Fenômeno" (Real Madrid): E\$ 17.4 milhões

4) Wayne Rooney (Manchester United): E\$ 16.1 milhões

5) Cristian Vieri (Mônaco): E\$ 16 milhões

6) Zinedine Zidane (Real Madrid): E\$ 15 milhões

7) Alessandro Del Piero (Juventus, Itália): E\$ 11.5 milhões

8) Frank Lampard (Chelsea): E\$ 9.8 milhões

9) Thierry Henry (Arsenal): E\$ 9.8 milhões

10) John Terry (Chelsea): E\$ 9.7 milhões

* Cerca de R\$ 63.250.000,00.

Fonte: Terra Esportes. 


\section{O negócio futebol}

O negócio futebol tem peso considerável na exportação brasileira. As vendas de jogadores estão entre os serviços exportados pelo país que apresentou aumento de 34\% em 2005 (cerca de US\$ 6 bilhões). Esse grupo de serviços representa $40 \%$ das exportações brasileiras (toda a exportação brasileira de serviços gerou US\$ 16 bilhões em 2005).

As vendas com atletas profissionais apresentaram o maior crescimento dos últimos oito anos em 2005, ano em que Robinho (candidato a "Pelé" ou, no mínimo, a Ronaldinho "Gaúcho") foi negociado com o Real Madrid: 55\%, ou US\$ 158,2 milhões! (Fonte: Banco Central) Só no primeiro bimestre de 2006 o negócio bateu em US\$25,8 milhões. Em 2004, foram realizadas 857 transferências registradas na CBF (Confederação Brasileira de Futebol); no ano passado, 804. É como se a cada dia dois a três jogadores fossem negociados (os maiores mercados: 40 atletas foram negociados com clubes do Japão, 20 da Alemanha, 15 da Arábia Saudita, 14 da Venezuela, 12 dos EUA e 9 do Irã).

Esses números "astronômicos" chamaram a atenção da Polícia Federal, que em dezembro de 2005 iniciou a "Operação Firula", cujo objetivo era (é?) o de desmontar "um grande esquema de transações financeiras ilícitas, envolvendo particularmente negociações com jogadores de futebol" (Fonte: PF). Nunca é demais lembrar que Kia Jorabchian, atual "poderoso chefão" do Corinthians, está no Brasil desde o final de 2004 como funcionário de gente ligada à "máfia russa", que passou a atuar sem obstáculos após o desmanche da União Soviética. As acusações a essa turma são gravíssimas, desde lavagem de dinheiro a crimes encomendados. Mas, se você perguntar a dez corintianos se eles estão preocupados com a origem do dinheiro que move o "Timão", provavelmente os dez dirão "não".

\section{Algumas das transações mais recentes envolvendo jogadores brasileiros para o exterior:}

Robinho (Santos FC): US\$ 30 milhões (Real Madrid)

Fred (Cruzeiro): E\$ 15 milhões (Lyon-França)

Vagner "Love": (SE Palmeiras): US\$ 10 milhões (CSK-Ucrânia)

Elano (Santos FC): US\$ 10 milhões (Shaktar-Ucrânia)

Kaká (São Paulo FC): US\$ 8,5 milhões (Milan)

Kleberson (Atlético Paranaense): E\$ 8,5 milhões

Diego (Santos FC): E\$ 8 milhões (FC Porto)

Cicinho (São Paulo FC): US\$ 7,2 milhões (Real Madrid)

Fonte: Terra Esportes. 
Ronaldinho "Gaúcho", 26 anos, o maior fenômeno do futebol mundial na atualidade, transferiu-se para o PSG (Paris Saint-Germain), da França, assim que seu contrato com o Grêmio de Futebol Portoalegrense terminou. Como o clube gaúcho não teve participação na formação do atleta, nada recebeu pela transação. Mas quando Ronaldinho se transferiu do PSG para o Barcelona, seu clube atual, o valor da transação foi de US\$ 30 milhões.

Ronaldo Nazário, o "Fenômeno", figura entre os detentores de grandes transações nos últimos tempos. Quando se transferiu da Inter, de Milão, para o Real Madrid, o valor foi de US\$ 50 milhões. Ronaldo está com 29 anos.

\section{Faturamento dos principais clubes europeus em 2005 (em euros)}

1) Real Madrid (Espanha): 275.7 milhões*

2) Manchester United (Inglaterra): 246.4 milhões

3) Milan (Itália): 234 milhões

4) Juventus (Itália): 229.4 milhões

5) Chelsea (Inglaterra): 220.8 milhões

6) Barcelona (Espanha): 207.9 milhões

7) Bayern (Munique, Alemanha): 189.5 milhões

8) Liverpool (Inglaterra): 181.2 milhões

9) Internazionale (Milão, Itália): 177.2 milhões

10) Arsenal (Inglaterra): 171.3 milhões

* Apenas para se ter uma idéia do montante, em nossa moeda isso equivale a 758.175.000,00 reais.

Fonte: Deloitte \& Touche.

Entre os motivos verificados para que as transações sejam realizadas em grande escala, pesa o fato de que as convocações para a Seleção Brasileira têm recaído cada vez mais apenas entre aqueles que atuam no exterior. Na convocação mais recente, feita pelo técnico Parreira no dia 15 de maio deste ano, visando à disputa da Copa da Alemanha, apenas dois jogadores atuam em equipes brasileiras: Ricardinho (Corinthians) e Rogério Ceni (São Paulo). Os demais 21 convocados atuam em clubes da Europa (Itália-6, Espanha-6, Alemanha-4, França-3, Inglaterra-1, Portugal-1).

Diante desse cenário deslumbrante, parece haver uma desordem mental que faz que as crianças-adolescentes (e, mais recentemente, os próprios pais) sonhem em "pertencer" a esse universo brilhante. Como impedir que uma família vivendo na linha da miséria, no sertão da Bahia, por exemplo, aceite os "favores" de um "empresário", que "doa" R\$ 1.500,00 (mil e quinhentos reais) e leva o filho de 16 anos para fazer um teste na Inglaterra? Isso ocorreu com Marcos Gonçalves. Passou no teste no Manchester United, mas, como tem só 16 anos, 
ficará treinando no Vitória, de Salvador, até que possa viajar sozinho para a Inglaterra. A outra opção em curso é a perpetrada por Wagner Ribeiro, empresário de Robinho, entre outros. Prometeu emprego para os pais de Neymar, de 14 anos, em Madri, para que o adolescente pudesse treinar no Real Madrid. Mas o Santos FC, onde treina o garoto desde criança, se antecipou e acertou com o empresário e com os pais que Neymar ficará na Vila Belmiro até os 16 anos. Depois, muito provavelmente, o Real Madrid o terá entre suas "minas de ouro".

Os dois exemplos citados acima contam com algum tipo de base e são registrados na CBF. Mas e aqueles que, de repente, aparecem nos jornais fazendo sucesso ou como protagonistas de grandes equívocos? Muitos embarcam em aventuras desastrosas (ver história de Douglas) e, às vezes, perigosas. E se, por acaso e muito provavelmente, a aventura não der certo?

O assunto é tão importante que provocou o surgimento de alguns estudos. Entre eles, o de Carlos Alberto Máximo Pimenta, bacharel em Direito e doutor em Ciências Sociais, pela PUC, de São Paulo, intitulado Sociologia da juventude: futebol, paixão, sonho, frustração, violência (Taubaté: Cabral Editora, 2006). Em seu trabalho, Pimenta aborda, entre outros assuntos, a seqüência que vai desde o sonho do garoto (de ser jogador de futebol), passando pelas projeções e expectativas, até bater na frustração de quem não conseguiu atingir o objetivo. Uma das conclusões mais importantes, a meu ver, é o que o autor chama de "frustração/fracasso de violência": "violência que, embora não verbalizada ou explicitada, inscreve-se de forma marcante na lembrança, na memória e na história de vida do iniciante-iniciado (o garoto que tenta ser jogador) e demarca sua trajetória em sociedade". Trocando em miúdos, sabe-se lá o que pode acontecer com um garoto absolutamente pobre que, com seus 19, 20 anos, após fracassar na tentativa, se vê diante de uma realidade áspera e agressiva, sem grandes ofertas a lhe fazer. O garoto - que "treinou e jogou os anos" que deveria ter utilizado para estudar - provavelmente se desorientará. E, caso não tenha alguém que trace um rumo ou the faça um planejamento, poderá facilmente enveredar pelo caminho das drogas, do álcool ou até do crime. Com esse olhar, sem dúvida, trata-se de uma violência.

A história dos seis garotos que viajaram para a Alemanha é exemplar, inclusive para esclarecer a relação entre os chamados "empresários" e os atletas ou aqueles que se preparam para sê-lo. E a história de Douglas, especificamente, melhor ainda.

\section{As histórias de alguns personagens}

Douglas dos Santos Rodrigues é um jovem de 20 anos. Pobre, mora com o pai na Vila Maria, zona norte de São Paulo. Sempre jogou bola e, como a maioria dos seus amigos, sonhou em ser jogador profissional. Aliás, ainda sonha, mesmo depois de ter vivido um inferno no início deste ano.

Atraídos pela fala fácil e convincente de um sujeito chamado Wilson Bellissi Jr., que não consta na lista dos 119 agentes brasileiros credenciados pela Fifa, 
mas que se auto-intitula "empresário", Douglas (com mais cinco amigos com idades variando dos 18 aos 21 anos) caiu na lábia do cidadão e acabou vivendo um pesadelo, em fevereiro de 2006. Bellissi prometeu ao grupo um contrato em uma equipe da Romênia. Para início de conversa, o "empresário" cobrou R\$ 1.500,00 (mil e quinhentos reais) de Paulo Roberto Rodrigues, pai de Douglas, para conseguir o registro profissional na CBF (custa cerca de R\$ 800,00). Rodrigues, que trabalha na Prodam (Companhia de Processamento de Dados do Município de São Paulo) e ganha quase R\$2.000,00 (dois mil reais), teve de vender o carro para desembolsar essa quantia, o valor da passagem (só de ida) de avião e todas as despesas com passaporte. No total, desembolsou um dinheiro que não tinha: R\$ 6.000,00 (seis mil reais). Mas o sonho do filho era o mais importante, e, depois, quem sabe, tudo retornaria, e em dobro! Durante o vôo, Douglas e seus amigos foram informados pelo irmão do "empresário" de que a equipe que defenderiam não era da Romênia, mas sim da Moldávia, também no leste europeu. Douglas nunca tinha ouvido falar da Moldávia. O avião fez escala em Frankfurt, Alemanha. Depois, o grupo rumou para o país de nome diferente, onde, segundo o olhar de Douglas, "só tinha gelo”. Chegando lá, ninguém os esperava. Além disso, ficou claro não haver nem contato, muito menos time para defender. Douglas e os amigos ficaram dois dias em um quartinho no aeroporto de Chisinau, capital do país, aguardando um desfecho da situação. Que não veio. Decidiram, então, retornar a Frankfurt. E esperaram uma definição por parte do "empresário", que ficara no Brasil. O que deveria durar apenas algumas horas, durou, no caso de Douglas, 21 dias! Ele e o grupo permaneceram no terminal, comendo mal (todas as refeições à base de lanche), dormindo mal (banco de madeira) e higienicamente bem mal (cada banho custava E\$ 6!).

O pai de Douglas, temendo que algo ainda mais grave pudesse ocorrer com o filho, mandou que ele retornasse ao Brasil. Os demais permaneceram em Frankfurt e acabaram se tornando amigos de uma brasileira, funcionária do aeroporto, que resolveu "adotá-los", dando-lhes comida, banho e teto. Douglas arrumou uma equipe de Mococa, interior de São Paulo, para jogar, e os amigos estão defendendo "alguma equipe alemã, mas não sei em que cidade; às vezes, ele me manda notícias por telefone. Tomara que Deus o proteja e que tudo dê certo.", diz a mãe de um deles. Wilson Bellissi Jr.? Está solto e tentando agenciar novos jogadores.

Profissionais também já viveram problemas no exterior. França, maranhense que fez história como artilheiro no São Paulo FC, mudou-se para a Alemanha, em 2002, a fim de defender as cores do Bayer Leverkusen. Com dificuldades de adaptação, principalmente por causa do frio e do idioma, passou meses sem fazer gols. Deprimido, quase voltou ao Brasil. Anos antes, Viola, que foi ídolo de uma das maiores torcidas do País (a do Corinthians), havia acertado com o Valência, da Espanha. Na época, embolsou um milhão de dólares pela transferência. Mas não suportou a solidão nem se adaptou ao estilo de vida naquele país. Voltou um mês depois de ter partido. 


\section{Ronaldinho}

Ronaldinho é amado em Barcelona. Chegou quieto, e foi ganhando a cidade e os catalães na base da labuta. Ronaldinho "gaúcho" é do tipo (raro) que não se ilude com o sucesso imenso. Acha tudo meio "normal", é o que havia traçado. Queria ser jogador de futebol desde sempre, e o que ocorre com ele hoje é apenas a seqüência natural das coisas. Rico, faturou cerca de 23 milhões de euros só na temporada passada. Tudo vem dando certo. Ronaldinho rapidamente captou o sentimento "independente" e de resistência do povo catalão e o encarnou. É como se batesse no peito, dizendo: "Sou catalão, não espanhol”. E o show de malabarismo tem início, o espetáculo de habilidade e inteligência comove a todos aqueles que gostam de futebol. Quando Ronaldinho destroçou quatro adversários e marcou aquele gol contra o Real Madrid, em pleno estádio Santiago Bernabeu, no $1^{\circ}$ turno do Espanhol-05/06, os catalães da cidade de Barcelona compreenderam haver ali um herói catalão, um verdadeiro representante de seus anseios separatistas. Mas, quando os madrilenhos se levantaram e o aplaudiram, de pé, o futebol mundial evoluiu. É como se todos os adversários do Barcelona no planeta Terra assumissem a condição de apaixonados pela magia do futebol jogado pelo garoto gaúcho de dentes atravessados, independentemente das cores de sua camisa. O futebol deve ser jogado por gente como Ronaldinho, e os garotos adolescentes que sonham com futebol sabem disso. Mas o mundo ainda não foi capaz de produzir apenas jogadores fora-de-série como ele.

\section{Zico}

No início dos anos 1980, após a realização da Copa do Mundo, na Espanha, em que o Brasil deu show, mas não foi campeão, houve um pequeno êxodo de jogadores profissionais de primeira grandeza para a Europa, especialmente a Itália. Falcão, Sócrates e Zico arrumaram suas malas e partiram. Falcão foi jogar em Roma, Sócrates em Florença e Zico na cidade de Údine.

Zico já era conhecido mundialmente e, na verdade, não encontrou nenhuma dificuldade para se adaptar à vida na cidade. Foi recebido e tratado com muito carinho pelos italianos. Fala Zico: "Falta dos amigos a gente sente (também o senti no Japão). Mas a comida italiana é fantástica e... minha preferida. Com exceção do frio, não enfrentei grandes problemas com a mudança. Já estava maduro, com filhos, por isso, não senti como acredito que sentiria se fosse um garoto de 16, 17 anos. Aquela foi uma experiência maravilhosa, como profissional e como homem. Aprendi sobre outra cultura, outro tipo de profissionalismo, como funciona um clube-empresa, e, pela minha dedicação e pelo meu rendimento, sou uma pessoa muito querida na Itália. Por onde passo as pessoas falam e lembram com carinho do período em que estive jogando por lá, principalmente das minhas cobranças de faltas. A Itália é um país maravilhoso, e sempre que posso curto uns dias lá, especialmente na Sardenha. Mas só conheci a Itália de verdade depois que parei de jogar, quando pude passear bastante. $\mathrm{Na}$ época de jogador era só aeroporto, hotel e estádio". 


\section{Hélio}

Eu tinha 24 anos e era repórter esportivo de rádio havia três anos. Mas continuava alimentando meu sonho de ser jogador de futebol profissional. O ambiente mágico dos estádios, especialmente à noite, me deixava eletrizado. No fundo, aquele era o meu lugar, eu sabia que ali poderia realizar as maiores façanhas e experimentar as maiores alegrias do meu viver.

Eu era excelente jogador. Além de habilidoso, era raçudo e marcava gols em praticamente todos os jogos que disputava nas escolas, nos pequenos estádios, na várzea. Em inúmeras ocasiões, levei o time nas costas ou dei-lhe a vitória. Um amigo me deu a idéia: "Por que não joga bola por uma universidade americana em troca de bolsa de estudos?". Do contato com a USIU (Universidade Internacional dos Estados Unidos) até o embarque para San Diego, no sul da Califórnia, passou-se quase um ano. Vendi tudo o que tinha (juntei apenas mil dólares) e entrei no avião. Mas, assim que cheguei à universidade, os problemas começaram. Segundo a secretária da escola, eu chegara "tarde", e, por isso, teria de desembolsar US\$2.500,00 (dois mil e quinhentos dólares) para morar no campus. Depois, fui apresentado ao técnico de futebol que, de cara, me descartou: "Você chegou tarde demais, acabaram-se as vagas. Treine amanhã, mas, mesmo que seja um "Pelé", não vai adiantar. É melhor voltar ao seu país". A partir daí, com visto de estudante e sem escola para estudar, tornei-me "cidadão ilegal". E minha aventura futebolística começou de verdade. Perambulei por inúmeras universidades, literalmente batendo à porta, à procura de alguém que se interessasse pelo meu futebol. Mas era outono, já não se jogava tanto por causa da temperatura. O máximo que consegui foi um time amador para jogar. $\mathrm{O}$ Newport Beach Soccer Club era formado, em sua maioria, por ingleses, mas ali havia iranianos, salvadorenhos, holandeses e até norte-americanos. A Liga era amadora, mas tinha como objetivo principal descobrir jogadores com potencial para brilharem na Liga Profissional. Três meses depois de ter chegado aos EUA, o dinheiro acabou e a solidão passou a pesar bastante. Não tinha amigos com quem conversar. Pelo contrário, vários jogadores do Newport Beach faziam troça de mim, aproveitando-se do fato de eu não dominar o idioma. Fui atrás de emprego: primeiramente, ajudante de garçom em um restaurante cinco estrelas; depois, faxineiro, lavador de veleiros, lixador e envernizador de barcos.

No verão de 1982 tive um acidente de moto grave e processei o cara que me havia atravessado. Ganhei um bom punhado de dólares e peguei um avião para Atenas, Grécia. Ao descer no aeroporto, fui literalmente escolhido por um taxista vidrado no futebol brasileiro. E que virou meu "empresário": "Amanhã, esteja pronto às nove em ponto que o levarei para um teste numa equipe daqui da cidade". Minha aventura grega durou quinze dias. Fiz um teste numa equipe amadora, e, depois no Panahayki, da cidade de Patras. Fui vítima de uma armação que me custou setecentos dólares. Peguei minha trouxa e desci na estação ferroviária de Lisboa, Portugal. Hospedei-me numa pequena pensão, e 


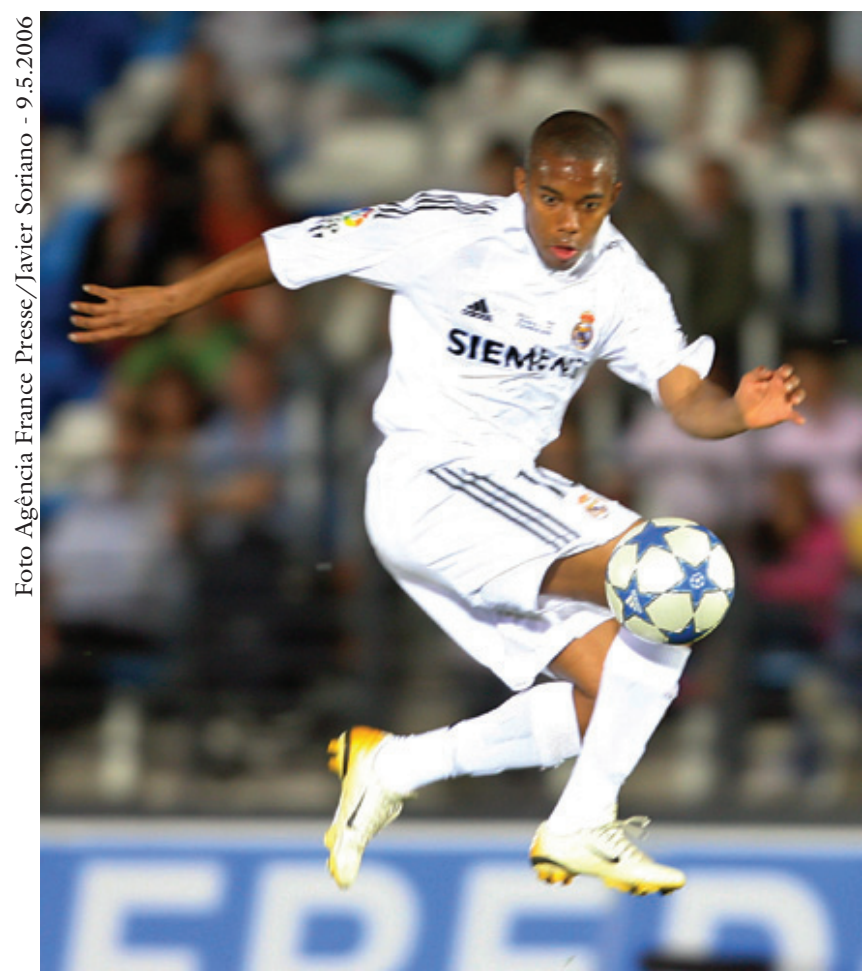

O jogador Robinho, do Real Madrid (Espanba).

dois portugueses, donos de uma fábrica de cerâmica, me levaram para o norte do país num caminhão lotado de galos de cerâmica. Me contrataram para defender o "Ceramistas", da aldeia de Galegos de São Martinho. Tinha casa, comida, roupa lavada e ajuda de custo, mas, como não havia registro nenhum na $\mathrm{CBF}$, nada feito. Peguei um ônibus para o Algarve, no extremo sul, onde os turistas despejam seus dólares e seus euros. Fui atrás dos veleiros, mas, novamente, o futebol me puxou. O diretor da Marina de Vilamoura, "encantado" com meu futebol, me "convocou" para disputar o torneio de verão, com a participação de várias equipes amadoras e semiprofissionais da região. Pela primeira vez na história da Marina, a equipe foi campeã, e eu o artilheiro. Fiz um jogo amistoso pelo Quarteirense, time da $3^{\text {a }}$ Divisão Profissional, mas, a essa altura, já estava bastante cansado de tentar viver da bola. Virei skipper (espécie de capitão) de um barco e marinheiro de outro, ganhando bons salários. Poucos dias depois do título, recebi dois convites para treinar no Sporting, de Lisboa, e no Porto, com tudo pago. Mas, exausto de tanta busca, disse "não, obrigado". E atravessei o Oceano Atlântico a bordo de um veleiro de 66 pés. Dessa maneira, três anos depois de minha chegada a San Diego, terminava meu sonho de ser jogador de futebol profissional. Hoje, pai de três filhos e com 50 anos de idade, ainda enfio a bola por entre as pernas de muito garotão de 20 anos!

Hélio Alcântara, jornalista e poeta, é colaborador da revista Caros Amigos, e chefe de redação na TV Cultura. 


\section{Parte de uma vida - quadro a quadro}

\section{Por Ivan Aguiar}

$M$

INHA EXPERIÊNCIA de vida nos Estados Unidos, onde cheguei em 14 de fevereiro de 1969, teve início cerca de dois anos antes, em junho de 1967. Com 18 anos completos, comecei a namorar uma moça em $\mathrm{BH}$, apenas um ano mais nova do que eu. Atleta, fisicamente bem preparado e mentalmente são, apaixonado, desejava casar-me, mas, e o dinheiro?

Como jogador de futebol, na época juvenil que ia até 21 anos de idade, abandonei os estudos, com o curso científico no último ano e fui procurar renda suficiente para realizar meu sonho. Um ano e meio depois, e várias tentativas, parecia-me que os empregos que eu tivera não me dariam a desejada condição financeira para sustentar uma casa e minha futura mulher. Eu precisava de um milagre. Entre várias tentativas, conheci um técnico de futebol, Álvaro Moreira Filogônio (Alvinho), que tinha sido recém-contratado pelo Atlético Goianiense (Goiânia), que, ao assumir o seu posto, convidou-me pessoalmente para fazer testes no clube.

Aceitando esta oportunidade, fui para a capital de Goiás, para acertar um contrato de experiência de três meses que me daria o direito de disputar o segundo turno do campeonato estadual.

Depois de três meses, nas vésperas de assinar o contrato definitivo, o técnico Alvinho me informou que estava aprovado pela comissão técnica, mas que ele havia recebido um convite para dirigir um clube nos Estados Unidos, com sede em Lowel (Massachusetts), patrocinado por uma fábrica de calçados sediada em Milford (Mass.). Disse-me então que, se eu quisesse ir também, eu não assinasse com o Atlético Goianiense, em contrato definitivo, pois, em três ou quatro meses, ele me chamaria para lá. Assim fiz. Disse aos goianos que havia repensado minha situação pessoal e queria voltar a Belo Horizonte.

Em $\mathrm{BH}$, comecei disputar campeonatos amadores para continuar em boa forma física.

Em novembro de 1968, recebi o chamado esperado. Fiz de minha namorada minha noiva, aliança compromisso e providenciei passaporte, visto de turista e pronto!

Em 14 de fevereiro, cheguei em Nova York, de terno tropical inglês, gravata de seda. Abotoaduras, blusa de cashimire argentino e... 14 graus abaixo de zero!!!

O Alvinho me esperava no saguão e me levou a uma loja no aeroporto internacional onde comprei botas próprias para inverno, duas calças de lã, meias, casaco de pele de alce forrado com pêlo de ovelha, blusão de nylon e pude sair de carro com destino a Boston e depois a Milford (Mass.) onde morei até vir embora para o Brasil em 22 de maio de 1971. 


\section{Vivenciando Marte!}

No dia seguinte à minha chegada, fui levado para a fábrica Porter Shoes, cujos sócios patrocinavam um clube de futebol semiprofissional, seja lá o que isso quer dizer, que disputava a recém-criada Liga dos Clubes da Nova Inglaterra.

Após a apresentação formal, com um tradutor português da Ilha da Madeira (além-mar) tentando me explicar direitos e deveres do contrato que me foi apresentado, solicitei que tentássemos um intérprete que falasse espanhol, castelhano ou assemelhado para facilitar-me o entendimento, visto que com o "portuga" não dava pé!

Primeira lição: português nos Estados Unidos esquece o português, não fala inglês. Fica incomunicável.

Parágrafo primeiro: nos Estados Unidos, você chega cansado, fuso horário em cima de você.

Não fala a língua pátria (deles), mas deve se reunir com seus patrões, aceitar intérprete que só interpreta e não traduz, e assinar o contrato.

\section{Reprogramação}

Assinei o contrato que o porto-riquenho González interpretou para mim e, no terceiro dia após a minha chegada, comecei a trabalhar na fábrica de sapatos e treinar à noite. Trabalhava de $7 \mathrm{~h} 30$ da manhã às $16 \mathrm{~h} 30$, com intervalos para almoço de meia hora e dois lanches de 15 minutos, de manhã e à tarde. Recebi no primeiro dia meu cartão de Social Security e meu número de conta bancária onde deveria depositar o meu salário semanal.

Em tempo, fui morar com o Alvinho, técnico do time, em um apartamento com um quarto grande, sala, cozinha, banheiro, contendo fogão, geladeira, televisão, armários etc., pagando quatorze dólares por semana, divididos em $50 \%$ para cada, inclusos aí água, luz e condomínio. Era um prédio de madeira de três andares, na principal rua da cidade.

\section{Finanças}

Minha renda semanal era de fábrica: operário não qualificado e sem falar inglês: 8 horas normais $-2,50 / \mathrm{h}=20,00 / \mathrm{d}$. 2 horas extras diárias $-5,00 / \mathrm{h}=$ $10,00 / \mathrm{d}$.

De segunda a sexta, ganhava 150 dólares; com as horas extras de sábado (quatro horas) $-2,50+1,25=3,75$ vezes $4 \mathrm{~h}=15,00$; na semana normal eu ganhava U\$ 175,00 (+-).

Como eu almoçava (lanche), tomava um forte café da manhã e nunca abandonei o hábito de jantar, gastava por semana: aluguel $=7,50$; alimentação $(\mathrm{U} \$+-6,00 / \mathrm{d})=36,00$; lavagem de roupas $=3,50$; frutas e outros $=4,00$; diversão e passeios $=15,00$; total das despesas $=$ U\$ 70,00 $(+$ ou- $)$

Contando com a receita do futebol, cerca de U\$ 200,00 ao mês, tinha a conta de receita e despesa assim: receita $=900 / 1000$ mês e despesa $=280 / 300$ mês. 
Informei à minha noiva que em meu regresso, com certeza, haveria casamento, casa completa, pelo menos dois fuscas na garagem, sem dívidas e alguma polpuda poupança no banco que, na época, pagava até $2,5 \%$ do saldo médio mensal, apenas por você ser seu correntista!! Aqui no Brasil!!!

Semanalmente, depositava parte do saldo do meu salário no banco americano e com outra parte comprava revistas, americanas é claro, que abrigavam em suas páginas internas meus suados dólares e, com apenas uma fita adesiva protegendo-as, enviava pelo correio para a minha mãe em $\mathrm{BH}$, que aplicava na Caixa Assistencial dos Funcionários da Loteria de Minas Gerais a até $4 \%$ de juros mensais, aguardando a minha volta. Minha mãe trabalhava lá e fazia parte da diretoria da "Caixa".

\section{Mistério!}

Até hoje fico pasmo pelo fato de um jovem de cerca de 19 anos ter chegado àquele país, sem falar sua língua por pelo menos 10 ou 11 meses, ser mão de obra não qualificada, operário de fábrica e do futebol e, em 2 anos e 2 meses, ter-se transformado já em seu país, o Brasil, na volta, em classe média/média e podido iniciar sua vida de casado sem uma só dívida, casa montada e dois fuscas na garagem. Deve ter sido um "portal" que eu atravessei sem perceber!

\section{Coisas do sindicato}

Após quatro meses de trabalho, durante uma tarde, notei que o encarregado da minha seção na fábrica e que ficava o tempo todo sentado numa cadeira semelhante à de um juiz de voleibol estava conversando com outra pessoa, que mais tarde soube ser representante do sindicato, olhando o tempo todo para mim. Pensei que não estava fazendo direito o meu trabalho e fiquei preocupado. Nos outros três dias que se seguiram, o fato repetiu-se. No quinto dia, veio o representante do sindicato falar comigo, apresentou-se e, por meio de um intérprete peruano, me explicou que a empresa estava satisfeita com meu trabalho e queria fazer uma proposta para melhorar meus ganhos e a minha própria produtividade. Como eu era estrangeiro, queriam falar comigo, mas assistido pelo sindicato. Informou-me que eu não obrigado a aceitar nada e que, se isso ocorresse, o sindicato passaria a me dar atenção especial a fim de evitar que houvesse por parte da fábrica qualquer pressão ou discriminação comigo.

Ao explicar-lhe que entendera claramente sua explicação, ele sorriu e me disse: "Agora, sob minha supervisão, vou autorizar ao encarregado falar com você”. Foi lá e voltou com o encarregado a tiracolo. Após perguntar-me se eu havia entendido tudo, explicou-me que quem ganhava por hora na América, ganhava sempre menos do que quem ganhava por produção (comissionista) e se propôs a ensinar-me como ser mais rápido na linha de produção especial, só de comissionados.

Levantou o estrado em que eu ficava trabalhando cerca de $10 \mathrm{~cm}$ para que meus cotovelos estivessem ligeiramente acima da bancada da máquina de costu- 
ra de solados de sapatos. Amassou uma cordinha na tesoura que eu usava para cortar sobras de linhas nos solados; amarrou também um elástico fino na caneta que eu usava para marcar a ficha de produção da grade de pares de sapatos; trocou a velocidade do motor da minha máquina de costurar sola e corpo do sapato para aumentar a minha velocidade de produção e explicou-me outros macetes.

Em três passei a faturar, em vez de U\$ 2,50 por hora, cerca de U\$3,75 por hora. A contagem não era mais por hora mas por peça (par de sapatos ou botas) e sim pelo número de pares fabricados por dia. Isso teve reflexos nas horas extras, é claro. Assim de U\$ 200 por semana, passei a ganhar cerca de U\$ 300 ou mais. Sem inflação a considerar, meu ganho praticamente dobrou!

\section{Lições de capitalismo}

Um dia, sexta-feira qualquer, entrei no banco onde depositava meus salários, dirigi-me ao caixa, saquei minha caderneta de depósitos e retiradas e fui fazer novo depósito. Eu tinha lá depositado cerca de U\$ 3.500. Com muitos sorrisos, a funcionária fez o meu depósito, anotou na caderneta meu novo saldo e disse-me que o gerente queria falar comigo. Fiquei apavorado! Devia alguma coisa a alguém? Fiz algo errado? Aguardei. O gerente saiu de sua sala sorridente, colocou a não no meu ombro e me levou à sua mesa. Falando devagar e claramente pronunciando cada palavra, disse-me: "Ivan, o que acontecerá com nosso país se todos os jovens promissores e trabalhadores deixarem de comprar coisas e deixar parado seu dinheiro num banco? Haverá queda na indústria, no comércio, desemprego, recessão. Você precisa adquirir o quê? Casa, carro, qualquer bem de consumo? O banco está aqui para lhe servir e orientar! Veja este catálogo de automóveis daquela loja da esquina. Escolha o seu! Você já tem a carteira internacional para dirigir? Nosso despachante providenciará a papelada! Quer comprar um pacote turístico para suas férias? Já tem seguro de vida e acidentes pessoais? Quer trazer alguém de seu país?”. E por aí foi...

Saí do banco proprietário de um Chevrolet Belair 68, lindo, financiado em doze meses pelo banco, repassado a mim e pronto. Custou U\$ $1.300 \mathrm{sem}$ entrada, parcelas fixas e sem juros!!! Descontado diretamente do meu salário com a devida autorização do sindicato. Minha carteira para dirigir chegou ao banco em uma semana e me foi entregue pelo "meu gerente".

\section{Preconceito}

Minhas relações na pequena cidade de Milford, pelo fato de ser jogador de futebol, estavam ampliando-se rapidamente. Gostaram de mim, cumprimentavam-me na rua e sorriam amistosamente.

Um dia, um sargento do corpo de bombeiros, cujo quartel ficava a uma quadra de onde eu morava, aproximou-se de mim na lanchonete onde eu tomava café da manhã todos os dias, pediu licença para sentar-se à minha mesa. Foi direto: "Eu e minha mulher fomos ao jogo de domingo passado e ficamos impressionados com duas coisas: sua habilidade em jogar o soccer e o fato de 
sabermos que você, por ser brasileiro e estrangeiro, ter que se sujeitar a morar com o técnico do seu time, um homem de cor!”.

Engasguei e não soube, durante pelo menos um minuto, o que dizer. $\mathrm{E}$ ele completou: "Queremos lhe oferecer um quarto lá em casa, bem barato, e apresentá-lo na escola para você dar aulas de soccer, mas morando com um negro fica difícil". Agradeci e continuei com o Alvinho e no nosso apartamento.

Segundo tempo: voltando num domingo à noite de Hadfort para Milford, após um jogo, percebemos que um carro de polícia estava nos seguindo há algum tempo. Suas luzes vermelhas piscando, nos autorizava a seguir em frente. Cerca de cinco minutos andando atrás de nós, eles ligaram as luzes azuis que significavam: "Se não parar, atiramos". Quem dirigia era o Alvinho (negro), no banco da frente, Nerival (negro), atrás, Dejair (negro) e eu, Ivan (branco). Paramos, ficamos dentro do carro com todos os vidros abertos. Um de cada lado, eles se aproximaram. Viram os negros e solicitaram que eu descesse do carro. Deram uns passos atrás, cada um de um lado do carro e um deles me perguntou educadamente: "Fala inglês?". Respondi que sim. "Você está bem?" "Sim." "Você conhece essa gente?" "Sim." "Está tudo bem mesmo?" "Fique aqui", disse ele. Dirigiu-se ao motorista e pediu carteira de motorista. Olhou bem para dentro do carro, verificou o rosto de cada um lá de dentro e dirigiu-se a mim perguntando se eu queria continuar com eles (os negros) ou queria uma carona até a cidade. Sem comentários.

\section{Posição social}

Trabalhando como operário e jogando futebol na então embrionária liga profissional de futebol dos Estados Unidos, qualquer um poderia viver com relativo conforto, possuindo todos os bens que a classe média brasileira possui ou deseja.

Não se pode, no entanto, dizer que as famílias americanas, operárias ou não, aceitariam que seus filhos namorassem ou se relacionassem conosco de igual para igual.

Parece que trabalhar pode, comprar pode, usufruir pode, mas misturar-se de verdade ainda não!

Após dois anos de trabalho e prática de futebol, obtive a condição que queria para casar. Voltei, casei, atingi plenamente meu objetivo. Encurtei o tempo, cresci, saí adolescente, voltei homem. Deu, portanto, tudo certo. Ah! menos o casamento.

Ivan Agniar é diretor do Araribá Esporte Cclube, agremiação tradicional da Pedreira Prado Lopes, bairro antigo de Belo Horizonte. Por meio de sua empresa, Consórcio Iatto Empreendimentos Ltda., realiza um trabalho de cunho social e esportivo. 


\section{Futebol e ciência}

\section{Por Sérgio Mascarenhas}

$\mathrm{U}$ M PARALELO muito instrutivo é o da análise entre o futebol e a ciência no Brasil. Muitos se perguntam por que o futebol brasileiro é pentacampeãol mundial, produz seguidamente astros mundiais como Pelé, Ronaldo, Ronaldinho Gaúcho, Zico e tantos outros, que fazem do Brasil um celeiro de craques. Todos "produtos de exportação de alto valor agregado", "portadores de futuro da alta tecnologia futebolística". Isto é demonstrado pela contratação de vários técnicos brasileiros por outros países para a disputa do mundial de 2006. Por que em ciência, tecnologia e inovação, embora tenhamos grandes valores de alto padrão internacional, não temos ainda nenhum Prêmio Nobel ou um Fields Prize (o Nobel da Matemática)? A explicação é fácil: a infância, a juventude e a população em geral fazem parte atuante da cultura futebolística. O número de campos de "peladas" é enorme, todo garoto pobre ou rico (mais pobres que ricos) é altamente motivado, social e culturalmente, para a prática do futebol, isto quase que espontaneamente, graças ao fato de que o futebol (mas não a ciência!) é uma cultura popular que impregna de maneira sustentável a sociedade.

Continuidade e sustentabilidade são fatores fundamentais para a quantidade com qualidade. Os investimentos em grandes estádios, os campeonatos municipais, estaduais, nacionais e internacionais são fortemente divulgados na mídia de maneira contínua, agitada e atraente. Os clubes (verdadeiras "escolas") têm incubadoras para garantir valores jovens, "olheiros" para contratar talentos e para aprender como jogam os futuros competidores, técnicos, fisioterapeutas, médicos e até psicólogos. Toda essa "cadeia produtiva" do futebol brasileiro não tem paralelo na ciência e tecnologia. Ciência, tecnologia e inovação ainda não fazem parte da cultura brasileira, onde não temos laboratórios nas escolas públicas ou se os temos são pouco usados, nem professores de ciências bem formados e sobretudo bem pagos, e com o prestígio social adequado (muito importante!).

Igualmente fundamental é o Deus Capitalista: Mercado! Isto é, enquanto as cadeias produtivas futebolísticas têm fortíssimo Mercado de bilhões de euros, dólares e yens, isto não acontece com o Brasil que exporta milhões de toneladas de commodities, quando também deveria exportar miligramas e nanogramas com alto valor agregado de conhecimentos. No entanto, no que tange ciência, tecnologia e inovação, o Brasil já provou que pode ter não só os seus "Pelés" (Prêmios Nobel) como grandes times (escolas científicas), grandes líderes (cientistas nucleadores e formadores de escolas e tradições sustentáveis) e principalmente geradores de centros emergentes. Para "florestar" o Brasil com talentos e "campos de várzea de ciências" (laboratórios escolares, feiras de ciências, olimpíadas, livros e divulgação científica através de museus e centros como preconizados pelos grandes José Reis, C. Pavan e Isaias Raw). Com isso, criaríamos não apenas 
“sequóias" (grandes laboratórios multidisciplinares e grandes redes temáticas), mas florestaríamos também o país com centros pequenos e médios, verdadeiras incubadoras de talentos. CNPq, Capes, Finep, Embrapa e Fapesp são magníficos exemplos de ações que podemos e devemos ser feitos. O atual ministro da Ciência e Tecnologia, Sérgio Machado Rezende e o atual presidente da Embrapa, Silvio Crestana, são exemplos de padrão internacional que nuclearam, cresceram e construíram ciência, tecnologia e inovação, estimulando e apoiando talentos pioneiramente. Mas, como o Brasil é o país da esperança, lembro também Anísio Teixeira, com quem tive a honra de trabalhar, e que me dizia com aquele brilho de sonhador no olhar: "Ainda vamos ter o Maracanã lotado para Educação e Ciência". Ou as palavras do Prêmio Nobel Abdus Salam, com quem também trabalhei em Trieste, na Academia de Ciências do Terceiro Mundo: "Nações sem Ciência e Tecnologia estão fadadas ao subdesenvolvimento". Para encontrar Pelés da Ciência, precisamos buscá-los nas favelas, nas várzeas, entre ricos e pobres, nas ruas e nos condomínios de luxo, e então teremos não apenas nossos almejados Prêmios Nobel, mas um Brasil mais justo e desenvolvido!.

Aproveito para agradecer a Pelé pelo carinho com que recebeu minha composição "Pelé: o gol do século", editada pelo Estúdio Berimbau São Carlos (SP) e que pode ser ouvida livremente no link: http://www.berimbauestudio. com.br/goldoseculo. Para uma análise científica da bicicleta de Pelé, vide o espetacular estudo de M. Duarte no link: http://www.usp.br/eef/lob/pele/bicicleta.htm

Sérgio Macarenhas é físico, professor emérito do Instituto de Física da USP de São Carlos e membro honorário do IEA-USP. 


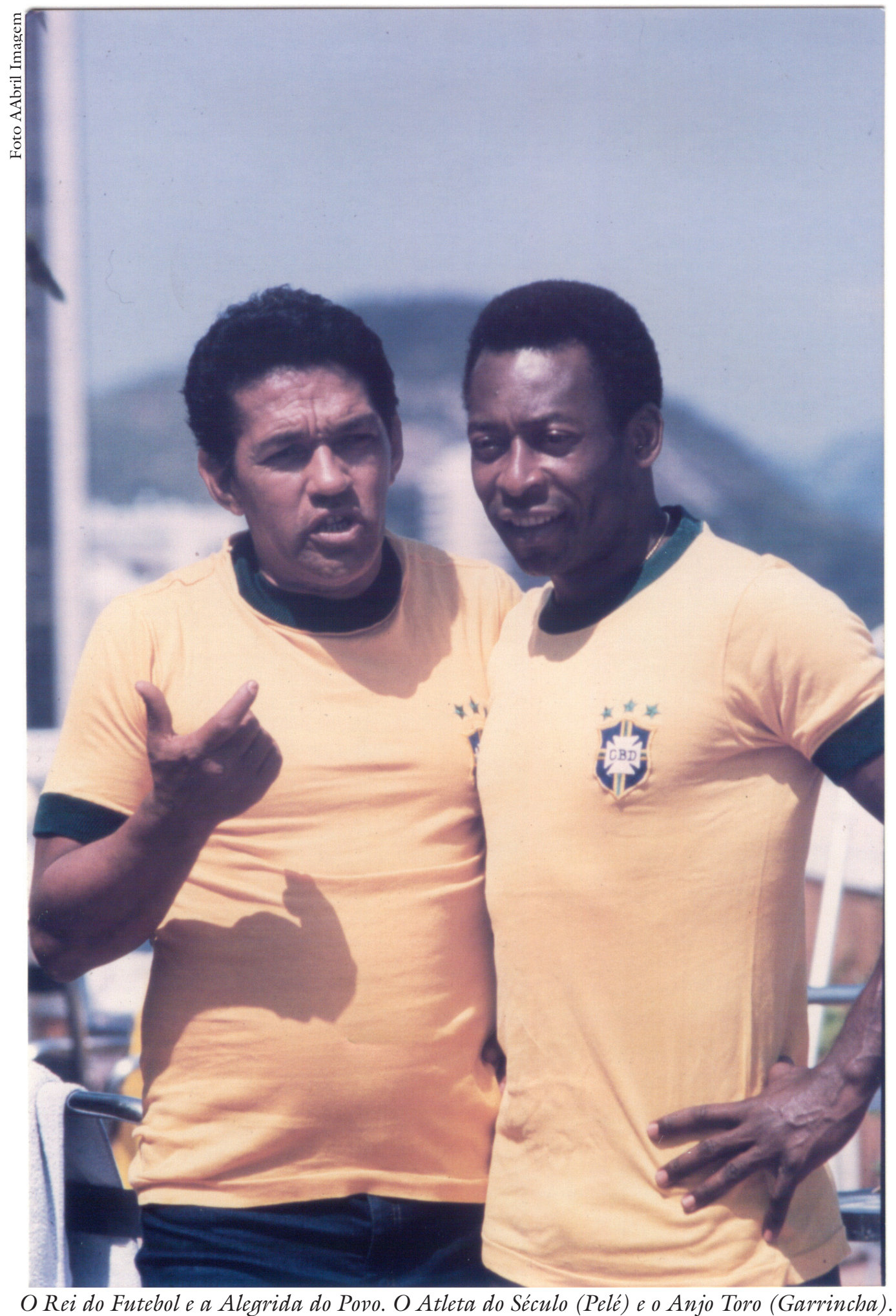

